\title{
Comparative Analysis of a Conserved Gene Block from the Genome of the Members of the Genus Ictalurivirus
}

\author{
Andor Doszpoly ${ }^{a}$ Mária Benkő ${ }^{a}$ Giuseppe Bovo ${ }^{b}$ Scott E. LaPatra ${ }^{c}$ \\ Balázs Harrach ${ }^{a}$ \\ ${ }^{a}$ Veterinary Medical Research Institute, Hungarian Academy of Sciences, Budapest, Hungary; \\ ${ }^{b}$ Istituto Zooprofilattico Sperimentale delle Venezie, Legnaro, Italy; ${ }^{C}$ Research Division, \\ Clear Springs Foods Inc., Buhl, Idaho, USA
}

\section{Key Words}

Alloherpesviridae $\cdot$ Ictalurivirus $\cdot$ Fish herpesvirus ·

Sturgeon $\cdot$ Black bullhead $\cdot$ Gene block $\cdot$ Subfamily

\begin{abstract}
Objective: Partial genome sequences were determined and subjected to comparative analyses from two fish herpesviruses (HVs). Acipenserid (Aci) HV-2, originating from the white sturgeon (Acipenser transmontanus), and ictalurid (Ic) $\mathrm{HV}-2$, isolated from the black bullhead (Ameiurus melas), are recently approved species of the genus Ictalurivirus of the family Alloherpesviridae. Methods: An almost 8,000-basepair fragment, spanning between the genes of the DNA polymerase and the ATPase subunit of the terminase, was sequenced from each virus. Results: The size, position and orientation of 2 partial and 3 full open reading frames, contained in the studied genome fragment, proved to be similar to their counterparts in IcHV-1, the type species of the genus Ictalurivirus. Thus, a well-conserved genus-specific gene block was identified. In the members of two other genera (Cyprinivirus and Batrachovirus) of the family Alloherpesviridae, no such gene block could be found; the location and orientation of the homologous genes showed significant divergence. Conclusion: The results of phylogenetic calculations were in good agreement with the genome arrange-
\end{abstract}

ments inasmuch as AciHV-2, IcHV-1 and -2 are monophyletic and separated from the lineages of the other two genera. The new sequence enabled the inclusion of a hitherto unassigned HV, that of the Australian pilchard, into a phylogenetic calculation.

Copyright $\odot 2011$ S. Karger AG, Basel

\section{Introduction}

The taxonomy of herpesviruses (HVs) has recently undergone major changes by the introduction of two novel families and the order Herpesvirales [1]. One of the new families, named Alloherpesviridae, allows proper classification of the HVs of anamnia, whereas the other family, the Malacoherpesviridae, contains a single genus, the Ostreavirus, with a single species, the Ostreid herpesvirus 1, the only HV of invertebrate origin [2].

The family Alloherpesviridae has been created to include the HVs isolated from fish and amphibians. Originally, only one, formerly unassigned, genus (Ictalurivirus) had been established with one species, the Ictalurid

The GenBank accession numbers of the sequences reported in this paper are FJ815289-815290.

\section{KARGER}

Fax +41613061234

E-Mail karger@karger.ch

www.karger.com
() 2011 S. Karger AG, Basel

$0300-5526 / 11 / 0545-0282 \$ 38.00 / 0$

Accessible online at:

www.karger.com/int
Balázs Harrach, DVM, PhD

Veterinary Medical Research Institute

Hungarian Academy of Sciences, Hungária krt. 21

HU-1143 Budapest (Hungary)

Tel. +361467 4081, Fax +361467 4076, E-Mail harrach@vmri.hu 
herpesvirus 1 (IcHV-1) [3]. In August 2009, three additional genera were approved (http://www.ictvonline.org). These include Cyprinivirus and Salmonivirus for the classification of HVs from cyprinid and salmonid fishes, respectively [4]. The third new genus, Batrachovirus, has been established to contain frog HVs (Ranid herpesvirus 1 and 2, RaHV-1 and -2). The classification of numerous additional fish HVs is hampered by the lack of a sufficient amount of, or sometimes even any, genomic sequence data. We study HVs isolated from ictalurid and acipenserid fishes.

To date, two HVs have been described from catfish, members of the Ictaluridae family. One of them is IcHV1 originating from the channel catfish (Ictalurus punctatus) [5]. The full genome sequence of IcHV-1 was published more than 15 years ago [6]. Because of its unique genome organization and gene content, IcHV-1 did not fit into any of the three subfamilies (Alpha-, Beta- or Gammaherpesvirinae), consequently an unassigned genus, Ictalurivirus, had been established to accommodate IcHV-1 within the family Herpesviridae [3]. The other catfish HV was isolated from the black bullhead (Ameiurus melas) in Italy in 1994 [7]. This virus has later been shown to be immunologically and genetically distinct from IcHV-1 [8]; however, no nucleotide (nt) sequence has been determined from it until recently $[4,9]$. The very first partial gene sequences of the black bullhead HV further confirmed its distinctness from IcHV-1. The approved name of this new virus species is Ictalurid herpesvirus 2 (IcHV-2).

From juvenile or adult, healthy or diseased sturgeons of different species (members of the Acipenseridae family), at least $7 \mathrm{HV}$ isolates are known presently [10]. Based on comparisons of sequences obtained from polymerase chain reaction (PCR)-amplified fragments from the viral DNA-dependent DNA polymerase and the ATPase subunit of the terminase gene, the assignment of the sturgeon HV strains has recently been revised [11] so that now they are divided into two types, namely Acipenserid herpesvirus 1 and 2 (AciHV-1 and -2). Detailed study of the genome of an AciHV-2 isolate (strain SRWSHV) originating from the white sturgeon (Acipenser transmontanus) is presently underway in our laboratory. This strain is the same isolate previously described as WSHV-99-ID-2 [10].

In the present paper, comparative analysis of an almost 8,000-base-pair (bp) genome fragment, encompassing 3 complete, and 2 partial genes from 2 viruses, IcHV2 and AciHV-2, is described. An attempt was made to compare the gene content of the examined DNA fragments with the respective genome region of other allo- herpesviruses. The results of partial genome analysis further confirmed both viruses as members of the genus Ictalurivirus. Furthermore, we observed the separation of 3 lineages that should probably be demarcated as subfamilies of Alloherpesviridae.

Among the yet unassigned HVs of fish is the one from the Australian pilchard (Sardinops sagax neopilchardus), which has been detected by PCR [12]. The only nt sequence determined from this virus is such a fragment of the ATPase subunit of its terminase gene that is not routinely targeted in diagnostic PCRs. Consequently, the putative pilchard HV (PHV) could not previously be included into phylogenetic studies. Our calculation presented in this paper is the very first attempt at the determination of the phylogenetic place of PHV.

\section{Materials and Methods}

\section{Virus Strains and Sample Preparation}

The origin and propagation of IcHV-2 and AciHV-2 have recently been summarized [9]. From IcHV-2 a lyophilized sample, from AciHV-2 the harvested fluid of infected tissue cultures were used. Processing of the samples for PCR has also been described in detail [9].

\section{Primer Design, PCR and Amplification Strategy}

The nt sequence of specific primers, for the amplification of a larger genome part of IcHV-2, was derived from the sequence of PCR products, amplified from two genes (of the DNA-dependent DNA polymerase and the terminase). A PCR for the amplification of an approximately 1,600-bp fragment from the DNA polymerase gene of alloherpesviruses has been described earlier [9]. For the amplification of a part of the first exon of the putative ATPase subunit of the terminase gene, coded by open reading frame (ORF) 62 in the IcHV-1 genome [6], degenerate consensus primers were designed. The primers, named Ic62Fo (5'-TTY CAR BTN GAR YTN ATG MGN GG-3') and Ic62Re (5'-TG NGC YTG NAC NAC DAT NTC DAT-3'), were selected using an amino acid (aa) alignment prepared from the ORF 62 of IcHV-1 and its homologues from the two ranid (Ra) HVs [13], and from AciHV-2. This latter sequence was derived from a HindIII clone originating from a random genomic cloning of AciHV-2 [unpublished results]. For the amplification of the 300-bp fragment of ORF 62, a PTC-200 DNA Engine Gradient Cycler (MJ Research) and the FailSafe $^{\text {TM }}$ PCR System (Epicentre ${ }^{\circledR}$ Biotechnologies) were used allowing easy optimization. The best performing reaction mixture contained $20.5 \mu$ l distilled water, $25 \mu$ l FailSafe ${ }^{\text {TM }}$ PCR $2 \times$ Premix F, $1 \mu$ l of each primer $(50 \mu \mathrm{M}), 0.5 \mu \mathrm{l}$ FailSafe $^{\mathrm{TM}}$ PCR Enzyme Mix, and $2 \mu \mathrm{l}$ of sample. The PCR program consisted of an initial step at $98^{\circ}$ for $5 \mathrm{~min}$, followed by 50 cycles with denaturation at $98^{\circ}$ for $45 \mathrm{~s}$, annealing at $46^{\circ}$ for $30 \mathrm{~s}$, and elongation at $72^{\circ}$ for $60 \mathrm{~s}$. The final extension was at $72^{\circ}$ for $10 \mathrm{~min}$.

To obtain the approximately 6,000-bp fragment between the DNA polymerase and terminase genes of IcHV-2, the Phusion ${ }^{\circledR}$ High-Fidelity DNA polymerase enzyme (Finnzymes) was used. 
The following PCR mix was found to be appropriate: $35 \mu$ distilled water, $10 \mu$ l Phusion ${ }^{\circledR} 5 \times$ HF buffer, $1.5 \mu$ l dNTP $(10 \mathrm{~mm})$, $1 \mu \mathrm{l}$ of each primer, $0.5 \mu l$ enzyme, and $1 \mu l$ target DNA. The PCR program consisted of an initial step at $98^{\circ}$ for $5 \mathrm{~min}$, followed by 50 cycles with denaturation at $98^{\circ}$ for $30 \mathrm{~s}$, annealing at $56^{\circ}$ for $30 \mathrm{~s}$, and elongation at $72^{\circ}$ for $4 \mathrm{~min}$. The final extension was at $72^{\circ}$ for $10 \mathrm{~min}$.

From AciHV-2, the sequence of the corresponding genome fragment was partially derived from the genomic HindIII clone, and partially from the amplicon generated by a PCR joining this genomic clone with the fragment obtained from the DNA-dependent DNA polymerase gene [9]. The estimated size of the joining PCR product was approximately $4,000 \mathrm{bp}$ and was obtained under reaction conditions essentially identical with those described above.

\section{Molecular Cloning and Sequencing}

The PCR products of about 6,000 and 4,000 bp, amplified from IcHV-2 and AciHV-2, respectively, were excised from $1 \%$ agarose gels after electrophoresis then purified and cloned with the use of the CloneJET ${ }^{\text {TM }}$ PCR Cloning Kit (Fermentas Life Sciences) according to the manufacturer's instructions. The vectors were transformed into a chemically competent Escherichia coli strain TOP $10^{\circledR}$ (iNtRON Biotechnology) with heat shock. Plasmid DNA was purified by the alkaline lysis miniprep method. For nt sequence determination, the pJET1 Forward and Reverse Sequencing Primers were used with the BigDye ${ }^{\circledR}$ Terminator v3.1 Cycle Sequencing Kit (Applied Biosystems) on an ABI 3100 Automated Capillary DNA Sequencer. To sequence the entire fragment, primer walking strategy was used. The approximately 300-bp fragment of the terminase gene (ORF 62) of IcHV-2 was sequenced directly with the PCR primers.

\section{Phylogenetic Analysis}

The nt sequence handling, processing, identification and analysis were carried out with freely available programs. The deduced aa alignments were made by the MultAlin program, using the default settings [14]. Phylogenetic calculations were performed online at the Mobyle portal (http://mobyle.pasteur.fr/cgi-bin/portal. py) of the Pasteur Institute (Paris) using distance matrix analysis (Protdist) with Jones-Taylor-Thornton matrix, then Fitch with global rearrangements [15]. The tree topology was confirmed by bootstrap analysis (Seqboot/1,000 samplings, Protdist, Fitch, Consense). The maximum-likelihood (Phyml) program with a Whelan and Goldman (WAG) matrix aa substitution model (1,000 samplings) was applied. Bayesian inference of phylogeny was calculated with MrBayes [16] applying the TOPALi v2.5 program package and interface [17] with the following parameters: number of runs: 4 , number of generations: 10 million, sample frequency 10 , burn in $25 \%$ with a WAG aa substitution model.

\section{Results}

\section{PCR and Cloning}

From the genome of IcHV-2, initially the sequence of a 300-bp fragment from the ATPase subunit of the terminase gene was determined. The genes of the DNA poly-
Table 1. Comparison of the size of 5 ORFs of IcHV-2 and AciHV2 with that of their counterparts in IcHV-1

\begin{tabular}{rlllll}
\hline $\begin{array}{r}\text { ORF: } \\
\text { Strand: }\end{array}$ & $\begin{array}{l}57+58 \\
+\end{array}$ & $\begin{array}{l}59 \\
-\end{array}$ & $\begin{array}{l}60 \\
+\end{array}$ & $\begin{array}{l}61 \\
-\end{array}$ & $\begin{array}{l}62 \\
+\end{array}$ \\
\hline IcHV-1 & 1,299 & 345 & 393 & 319 & 212 \\
IcHV-2 & 1,299 & 345 & 397 & 313 & 212 \\
AciHV-2 & 1,297 & 339 & 348 & 324 & 218 \\
\hline
\end{tabular}

Size is given in aa. The table shows the full size of ORFs 59, 60 and 61. From ORF $57+58$ (coding for the DNA polymerase) and ORF 62 (the ATPase subunit of the terminase gene), only partial sequences of IcHV-2 and AciHV-2 are compared with the corresponding fragments of IcHV-1.

merase and the terminase were connected by a PCR, the product of which proved to be $6,400 \mathrm{bp}$ in length. After assembling the sequences of the fragments, a 7,982-bp continuous genome part of the IcHV-2 was obtained that corresponded to the stretch between the 214th aa of ORF 57 and the 212th aa of ORF 62 of the IcHV-1 genome [6].

From AciHV-2, the final size of the studied genome region was $7,925 \mathrm{bp}$. Its sequence was derived from the approximately 10,500-bp cloned HindIII and from the amplicon generated by the PCR joining ORF 60 and the DNA polymerase gene (ORF $57+58)$. The AciHV-2 genome fragment could also be aligned with the IcHV-1 genome from the 214th aa of ORF 57 to the 212th aa of ORF 62. The GenBank accession numbers of the two sequences are FJ815289 and FJ815290.

\section{Genetic Organization}

In both viruses, the examined genome part contained 3 complete and 2 partial ORFs. When using Blast programs, homology of highest score was always found with the corresponding ORFs of IcHV-1. The size, orientation and relative position of the genes were similar to, or identical with, their counterparts in IcHV-1 as shown in table 1 . An identity/similarity table of the aa sequence of the predicted gene products of IcHV-2, AciHV-2 and 4 fully sequenced alloherpesviruses as compared with their counterparts in IcHV-1 is presented in table 2 .

The gene arrangement of the genome fragments is presented schematically in figure 1. For comparison, four representatives of two of the three other genera of the family Alloherpesviridae are also shown. While the three ictaluriviruses (IcHV-1 and -2, and AciHV-2) have identical layouts, it was difficult to decide which genome part of the cyprinid (CyHV-3), anguillid (AngHV-1) and the 
Table 2. Comparison of the identity (ID) and similarity (SIM) of the deduced aa sequences of 5 ORFs of IcHV-2, AciHV-2, CyHV-3, AngHV-1, RaHV-1 and -2 to the corresponding proteins of IcHV-1

\begin{tabular}{|c|c|c|c|c|c|c|c|c|c|c|c|c|}
\hline & \multicolumn{2}{|c|}{ IcHV-2 } & \multicolumn{2}{|c|}{ AciHV-2 } & \multicolumn{2}{|c|}{ CyHV-3 } & \multicolumn{2}{|c|}{ AngHV-1 } & \multicolumn{2}{|c|}{ RaHV-1 } & \multicolumn{2}{|c|}{ RaHV-2 } \\
\hline & ID & SIM & ID & SIM & ID & SIM & ID & SIM & ID & SIM & ID & SIM \\
\hline ORF $57+58$ & 73 & 83 & 56 & 72 & 26 & 42 & 27 & 42 & 26 & 42 & 26 & 43 \\
\hline ORF 59 & 61 & 78 & 27 & 57 & - & - & - & - & - & - & - & - \\
\hline ORF 60 & 60 & 76 & 40 & 60 & 28 & 43 & 26 & 46 & 23 & 39 & 31 & 51 \\
\hline ORF 61 & 55 & 72 & 31 & 51 & - & - & - & - & - & - & - & - \\
\hline ORF 62 & 79 & 90 & 57 & 73 & 30 & 51 & 31 & 49 & 30 & 54 & 34 & 53 \\
\hline
\end{tabular}

Values are shown as percentages. - shows that no homologue of the given ORF of IcHV-1 could be identified. ID or SIM values $>50 \%$ are set in bold letters. The ID and SIM values of genes situated far away from ORF 60 are set in italics.

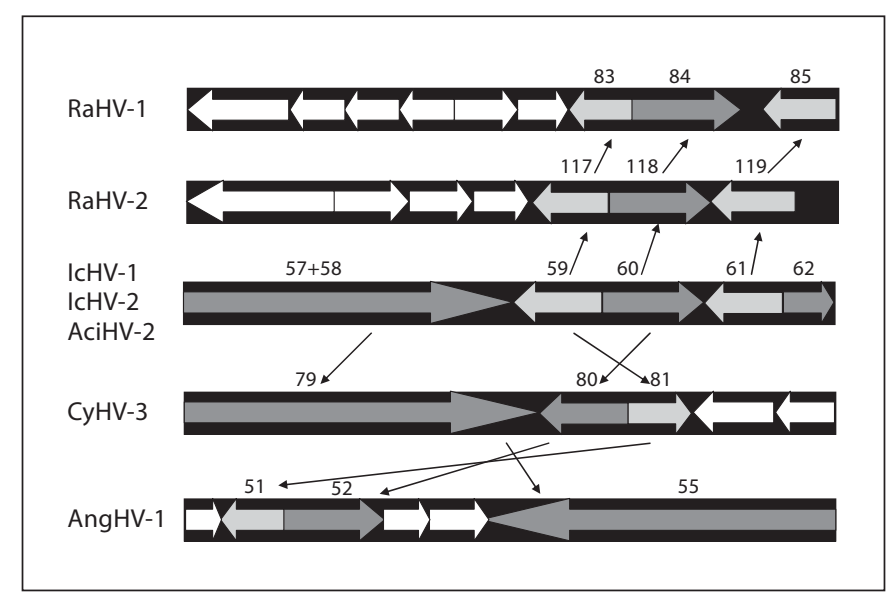

Fig. 1. The gene block conserved in the genome of IcHV-1 and -2 , and AciHV-2 between and including the genes DNA-dependent DNA polymerase (ORF $57+58)$ and ATPase subunit of terminase (ORF 62). For comparison, a genome fragment of similar size from AngHV-1 [22], CyHV-3 [21], RaHV-1 and -2 [13] are shown. In these latter two viruses, the homologues of ORF $57+$ 58 and ORF 62 are differently and distantly located; therefore, the surroundings of the homologues of ORF 60 are presented. The ORFs are presented by arrows proportional in size. Dark grey arrows mark convincing homology; light grey arrows represent positional counterparts. Line arrows indicate ORFs that are homologues or positional counterparts. ORF numbers of homologous genes are above the arrows.

two RaHVs should be included. In these viruses, the DNA polymerase and the terminase genes are contained in distant genome regions, thus the surroundings of these genes are also very different. We selected the central gene (ORF 60) of the examined block as a core of the comparison. This enabled inclusion of more than one homolo- gous gene from the members of the other two (Cyprinivirus and Batrachovirus) genera (fig. 1).

The first ORF in the examined gene block of ictaluriviruses is ORF 57(+58), which codes for the catalytic subunit of the DNA-dependent DNA polymerase [18]. This is one of the best conserved genes among the members of the family Herpesviridae and is frequently used as a target to detect HVs by PCR $[19,20]$. This gene is in the vicinity of the homologue of ORF 60 of IcHV-1 in CyHV-3, and, though in reverse orientation, also in AngHV-1. Interestingly, in RaHVs the corresponding ORF is very far from the homologue of ORF 60.

The predicted product of the next ORF (ORF 59) is a putative envelope protein with multiple transmembrane domains. The ORFs 83 and 117 of RaHV-1 and RaHV-2, respectively, have been described as positional counterparts of ORF 59 of IcHV-1 [13]; nevertheless, detectable homology does not exist between these proteins and ORF 59. In CyHV-3, the ORF 81 is a multiple transmembrane protein, and a positional counterpart of ORF 59, although in inverted orientation [21]. In AngHV-1, the ORF 51 is a homologue of ORF 81 of CyHV-3 [22].

The function of ORF 60 is yet unknown. It seems to be conserved in RaHV-1 (ORF 84) and -2 (ORF 118) [13], in AngHV-1 (ORF 52) as well as in CyHV-3 (ORF 80), albeit in inverted orientation [21].

The function of ORF 61 is also unknown. Besides RaHV-1 and -2 (ORF 85 and ORF 119, with marginal sequence homology only) [13], its homologue is also conserved in salmonid herpesvirus 2 (SalHV-2) [23] but not in CyHV-3 and AngHV-1.

ORF 62 of IcHV-1 encodes the putative ATPase subunit of the terminase. This gene seems to be conserved throughout the entire order Herpesvirales including Os- 


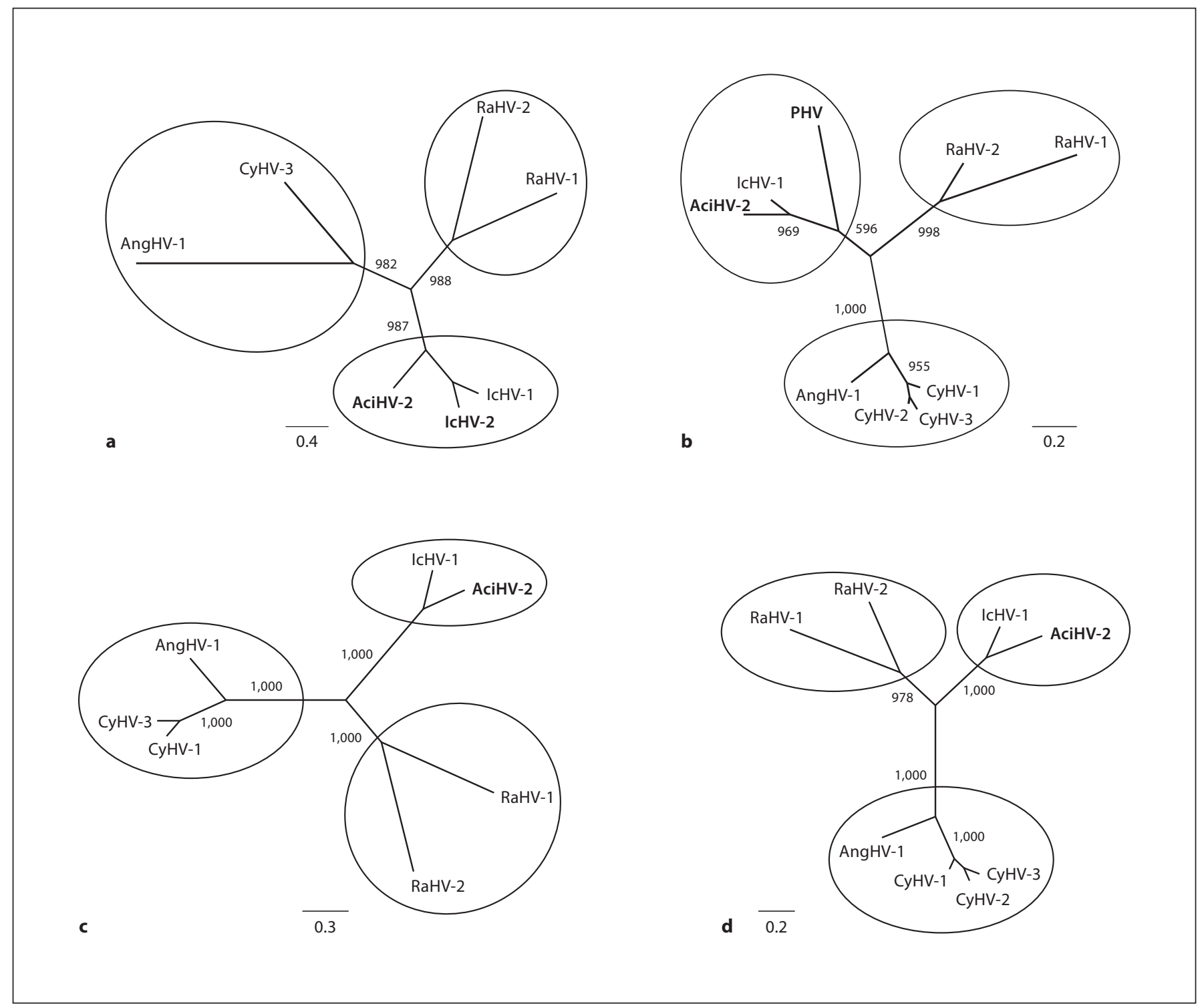

Fig. 2. Phylogenetic tree reconstructions based on maximum likelihood analyses of aa sequences. a Homologues of ORF 60 of IcHV-1 available from fish and frog alloherpesviruses; 327-aa alignment. High bootstrap values confirm the branching topology. b Partial aa sequences of the ATPase subunit of the terminase from fish and frog HVs (123-aa alignment). c Full aa sequences of the DNA-dependent DNA polymerase; 1119-aa alignment. d Complete aa sequences of the first exon of the ATPase subunit of the terminase; 267-aa alignment.

treid herpesvirus 1, the HV of bivalve molluscs [24], which is now classified in the new genus Ostreavirus of the new family Malacoherpesviridae [1]. The position of the homologues of ORF 62 is rather different in the members of the different alloherpesvirus genera. As can be seen in figure 1, neither CyHV-3, nor AngHV-1 or RaHVs contain it near their DNA polymerase or ORF 60 homologues.

\section{Phylogenetic Calculations}

The phylogenetic tree reconstruction obtained by maximum-likelihood analysis of the deduced aa sequence of ORF 60 of IcHV-1 and its homologues from 6 additional HVs is presented in figure 2a. The final length of the alignment was 327 aa. The branching topology of the trees obtained by Bayesian inference or distance matrix analysis (not shown) was identical with that of the 
maximum-likelihood tree. Compared with the DNA polymerase gene, which is most frequently used in phylogenetic analyses $[9,10]$, ORF 60 shows larger variations among the different frog and fish HVs. Nonetheless, the topology of the tree is similar to that obtained by calculations with the DNA polymerase sequences and clearly shows the separation of three main clades that should probably be separated as subfamilies.

The separation of three main groups was also supported by the values of the identity/similarity percentages among the proteins presented in table 2 . Within the genus Ictalurivirus, the similarity values exceeded $50 \%$, while members of the genera Batracho- and Cyprinivirus had significantly lower values, or missed the homologous gene in this region.

The phylogenetic tree in figure $2 \mathrm{~b}$ presents the results obtained with maximum-likelihood analysis of a shorter fragment consisting of merely 123 aa, of the terminase. The topology was also identical with that of the Bayesian or distance matrix trees (not shown). Although from most alloherpesviruses, another part of the terminase gene has been amplified by PCR, choosing this region allowed us to include the HV described from the Australasian pilchard [25] into a phylogenetic analysis for the very first time. From the putative PHV, this is the only nt sequence available [12]. For further confirmation of the tree topology, maximum-likelihood trees were also constructed on the full sequence of the DNA polymerase (fig. 2c) and the entire first exon of the ATPase subunit of the terminase (fig. $2 \mathrm{~d}$ ). The branching patterns of these trees also showed the clear separation of three main clades.

\section{Discussion}

Molecular study and sequence analysis of HVs of lower vertebrates have accelerated in the past few years, leading ultimately to radical changes in the official taxonomy [1]. Division of the new family and assignment of new species of alloherpesviruses into different genera are now in progress. Alloherpesviruses have been detected only in amphibian and piscine hosts so far. The list of unassigned HVs of such hosts [4] indicates the importance of thorough discussion and definition of the demarcation criteria of the different novel taxa (genera and subfamilies). In modern taxonomy, a good taxon primarily reflects the evolutionary relationships.

The host spectrum of the members of the genus Ictalurivirus includes bony and chondrostean fishes. Besides the close phylogenetic relationships between the IcHVs and AciHV-2, the identical gene arrangement of the examined genome fragment also justifies the classification of these viruses in a common genus. On the other hand, in spite of its host origin, AciHV-1 could not be placed into the same genus and remains in an unassigned position.

One novel genus is Salmonivirus that was established for the classification of SalHV-1 of the rainbow trout (Oncorhynchus mykiss) and for SalHV-2 of the cherry salmon (Oncorhynchus masou masou) [4, 26]. Analysis of short sequences of SalHV-3, originating from the lake trout (Salvelinus namaycush) has shown that this virus could also be a member of this genus [4]. However, from the SalHVs, full genome sequences have not been published, thus none of them could be included into the present comparative study of this particular gene block. According to phylogenetic trees published earlier, the genus Salmonivirus is closest to Ictalurivirus, and should likely be classified into a common subfamily.

The other new genus, Batrachovirus, is populated by the two RaHVs [1]. Our phylogenetic calculations (fig. 2) showed that the genetic distance between RaHV-1 and RaHV-2 might be larger than expected within a genus. The phylogenetic tree reconstructions published earlier [4] also suggest that the distance between the two RaHVs is equal with, or even exceeds, the distance separating the other two genera, Ictalurivirus and Salmonivirus.

The third new genus, Cyprinivirus, has been introduced for the classification of $\mathrm{HV}$ species originating from cyprinid fishes [4]. CyHV-1 and -2 have been isolated from the common carp (Cyprinus carpio carpio) and goldfish (Carassius auratus), respectively [27, 28]. From these viruses, several full [29] or partial gene sequences have been published $[30,31]$. The third virus species in the genus is CyHV-3 from strains of the common carp including the koi carp (Cyprinus carpio koi). The complete genome sequences of three CyHV-3 isolates have been determined and analyzed [21]. Most recently, the full genome sequence of AngHV-1 has been published $[22,32]$. Although AngHV-1 is a close relative of cypriniviruses, it was proposed to be a member of a separate genus.

The genome size of RaHV-1 and - 2 is comparable (220 and $230 \mathrm{kbp}$, respectively), and they share a number of conserved gene blocks that include 40 ORFs [13]. When the genome of IcHV-1 is also included in the comparison, the number of conserved ORFs diminishes to 19. With the consideration of CyHV-3, only 13 homologous genes remain shared by every alloherpesvirus [21]. Finally, with 
the inclusion of the AngHV-1 genome, the number of convincingly homologous genes drops to 12 [22]. Thus in general, members of the family Alloherpesviridae, containing fewer common ancestral genes, seem to be more diverse than those of the Herpesviridae. The so-called conserved blocks usually contain just a couple of genes of clear homology, whereas in many cases positional counterparts with only marginal, or even without any, sequence similarity have been described [13].

In the genome fragment examined in this study, all the 5 ORFs show convincing homology in the 3 members of the genus Ictalurivirus. The size and orientation of these ORFs were also found to be very close or identical. Although the size of the full genome of AciHV-2 and IcHV2 is yet to be determined, the present findings strongly confirm the classification of AciHV-2 and IcHV-2 into the genus Ictalurivirus.

Interestingly, in the genome of RaHV-1 and -2 , the genes of the DNA polymerase (ORF 72 and 110) and the terminase (ORF 42 and 68) are located far from each other and also from the deemed homologues of the (IcHV-1) ORF 59, 60 and 61. Of the 3 ORFs, only ORF 60 has convincing homologues in RaHV-1 (ORF 84) and RaHV-2 (ORF 118), whereas the homology of ORF 83 and 117, as well as of ORF 85 and 119 (of RaHV-1 and -2, respectively) to ORF 59 or ORF 61 of IcHV-1 is only hypothesized. These findings in the genome organization and the huge difference between the genome sizes of RaHVs and IcHVs confirm the results of the phylogenetic calculations, that at least 3 main lineages can be seen in the family Alloherpesviridae. Interestingly, in the genome of $\mathrm{CyHV}-3$ and AngHV-1, the homologues of ORF 60 are located near the gene of the DNA polymerase but in inverse orientation (fig. 1). On the other hand, the terminase gene (ORF 62) is situated in a different region, and no homologues of analyses $[4,9]$. The short fragment available from its terminase gene [12] has been obtained with primers different from those used in diagnostic PCRs [4]. The termicomparison with PHV. Although the size of the compaas a member of the cluster (subfamily) where ictaluriviruses belong, but the distance suggests that a novel genus could be established. The first phylogenetic calculations published with fish HVs have also been based on equally short sequences, yet the results could later be unambiguously strengthened. Apparently, these genes are con-

served enough to yield reliable results. The more detailed molecular characterization of PHV and AciHV-1 would be especially important because these viruses seem to be outstanding from the existing genera. Moreover, AciHV-1 may represent even a separate subfamily. Since there is no hope for the isolation of PHV in the near future, its further study could be attempted with an approach that had been applied successfully for the sequencing of a nonisolated adenovirus detected in a great tit [33]. The method was a nonspecific DNA amplification by isothermal multiple displacement whole-genome amplification [34].

Additional fish species, known to have specific HVs, include the turbot (Scophthalmus maximus), northern pike (Esox lucius), and Japanese flounder (Paralichthys olivaceus), but either no sequence data are known (from the first two viruses), or the published sequence (from the flounder HV) is not similar to any known sequence and is therefore not suitable for comparisons [35-38]. Consensus PCRs targeting the DNA-dependent DNA polymerase and/or the ATPase subunit of the terminase gene could help in elucidating the phylogenetic status of these viruses. Additional in-depth studies are necessary to explore the biodiversity represented by HVs of lower vertebrates, and to further elaborate the subdivision of the new family Alloherpesviridae.

\section{Acknowledgement}

This work was supported by a grant (OTKA K61317) provided by the Hungarian Scientific Research Fund. ORF 59 and 61 of IcHV-1 could be detected.

In the absence of corresponding nt sequence data, the PHV has not been included into previous phylogenetic nase sequence from AciHV-2 and IcHV-2 allowed a direct rable fragment is only 123 aa, it seemed to identify $\mathrm{PHV}$

References

\footnotetext{
1 Davison AJ, Eberle R, Ehlers B, Hayward GS, McGeoch DJ, Minson AC, Pellett PE, Roizman B, Studdert MJ, Thiry E: The order Herpesvirales. Arch Virol 2009;154:171-177.

-2 Davison AJ, Trus BL, Cheng N, Steven AC, Watson MS, Cunningham C, Le Deuff RM, Renault T: A novel class of herpesvirus with bivalve hosts. J Gen Virol 2005;86:41-53.

3 Davison AJ, Eberle R, Ehlers B, Hayward GS, McGeoch DJ, Minson AJ, Pellett PE, Roizman B, Studdert MJ, Thiry E: Family Herpesviridae; in Fauquet CM, Mayo MA, Maniloff J, Desselberger U, Ball LA (eds): Virus Taxonomy, VIIIth Report of the International Committee on Taxonomy of Viruses. London, Elsevier, Academic Press, 2005, pp 193212 .
} 
$\checkmark 4$ Waltzek TB, Kelley GO, Alfaro ME, Kurobe T, Davison AJ, Hedrick RP: Phylogenetic relationships in the family Alloherpesviridae. Dis Aquat Organ 2009;84:179-194.

$\checkmark 5$ Wolf K, Dalringtron RW: Channel catfish virus: a new herpesvirus of ictalurid fish. J Virol 1971;8:525-533.

6 Davison AJ: Channel catfish virus: a new type of herpesvirus. Virology 1992;186:9-14

7 Alborali L, Bovo G, Lavazza A, Cappellaro $\mathrm{H}$, Guadagnini PF: Isolation of an herpesvirus in breeding catfish (Ictalurus melas). Bull Eur Assoc Fish Pathol 1996;16:134-137.

8 Hedrick RP, McDowell TS, Gilad O, Adkison M, Bovo G: Systemic herpes-like virus in catfish Ictalurus melas (Italy) differs from Ictalurid herpesvirus 1 (North America). Dis Aquat Organ 2003;55:85-92.

-9 Doszpoly A, Kovács ER, Bovo G, LaPatra SE, Harrach B, Benkő M: Molecular confirmation of a new herpesvirus from catfish (Ameiurus melas) by testing the performance of a novel PCR method, designed to target the DNA polymerase gene of alloherpesviruses. Arch Virol 2008;153:2123-2127.

10 Kelley GO, Waltzek TB, McDowell TS, Yun SC: Genetic relationships among herpes-like viruses isolated from sturgeon. J Aquat Anim Health 2005;17:297-303.

-11 Kurobe T, Kelley GO, Waltzek TB, Hedrick RP: Revised phylogenetic relationships among herpesviruses isolated from sturgeons. J Aquat Anim Health 2008;20:96102.

-12 Crockford M, Jones JB, Crane MSJ, Wilcox GE: Molecular detection of a virus, Pilchard herpesvirus, associated with epizootics in Australasian pilchards Sardinops sagax neopilchardus. Dis Aquat Organ 2005;68:1-5.

-13 Davison AJ, Cunningham C, Saurbier W, McKinnell RG: Genome sequences of two frog herpesviruses. J Gen Virol 2006;87: 3509-3514.

14 Corpet F: Multiple sequence alignment with hierarchical clustering. Nucleic Acids Res 1988; 16:10881-10890.

15 Felsenstein J: PHYLIP-Phylogeny inference package. Cladistics 1989;5:164-166.

16 Huelsenback JP, Ronquist F: MrBayes: Bayesian inference of phylogeny. Bioinformatics 2001;17:754-755.

$\checkmark 17$ Milne I, Wright F, Rowe G, Marshall DF, Husmeier D, McGuire G: TOPALi: software for automatic identification of recombinant sequences within DNA multiple alignments. Bioinformatics 2004;20:1806-1807.
18 Davison AJ: GenBank submission updated by the Author. Accession No NC_001493. 2008.

19 Hanson LA, Rudis MR, Vasquez-Lee M, Montgomery RD: A broadly applicable method to characterize large DNA viruses and adenoviruses based on the DNA polymerase gene. Virol J 2006;3:28.

20 Ehlers B, Küchler J, Yasmum N, Dural G, Voigt S, Schmidt-Chanasit J, Jäkel T, Matuschka FR, Richter D, Essbauer S, Hughes DJ, Summers C, Bennett M, Stewart JP, Ulrich RG: Identification of novel rodent herpesviruses, including the first gammaherpesvirus of Mus musculus. J Virol 2007;81: 8091-8100.

21 Aoki T, Hirono I, Kurokawa K, Fukuda H, Nahary R, Eldar A, Davison AJ, Waltzek TB, Bercovier H, Hedrick RP: Genome sequences of three koi herpesvirus isolates representing the expanding distribution of an emerging disease threatening koi and common carp worldwide. J Virol 2007;81:5058-5065.

- 22 van Beurden SJ, Bossers A, VoorbergenLaarman MHA, Haenen OLM, Peters S, Abma-Henkens MHC, Peeters BPH, Rottier PJM, Engelsma MY: Complete genome sequence and taxonomic position of anguillid herpesvirus 1. J Gen Virol 2010;91:880-887.

23 Bernard J, Lamoureux-Mercier A, Lefevre F: Comparison of the organization of ORFs 61 and 62 and internal repeat of Salmonis herpesvirus 2 and Ictalurid herpesvirus 1, two fish viruses. GenBank Accession No. X81060. 1994.

24 Batista FM, Arzul I, Pepin JF, Ruanod F, Friedman CS, Boudry P, Renault T: Detection of Ostreid herpesvirus 1 DNA by PCR in bivalve molluscs: a critical review. J Virol Methods 2007;139:1-11.

25 Crockford M, Jones JB, McColl K, Whittington RJ: Comparison of three molecular methods for the detection of pilchard herpesvirus in archived paraffin-embedded tissue and frozen tissue. Dis Aquat Organ 2008; 82:37-44.

26 Davison AJ: The genome of salmonid herpesvirus 1. J Virol 1998;72:1974-1982.

27 Sano T, Fukuda H, Furukawa M, Hosoya H, Moriya Y: A herpesvirus isolated from carp papilloma in Japan. Fish Shellfish Pathol 1985;32:307-311.

28 Jung SJ, Miyazaki T: Herpesviral haematopoietic necrosis of goldfish, Carassius auratus (L.). J Fish Dis 1995;18:211-220.
9 Waltzek TB, Kelley GO, Stone DM, Way K, Hanson L, Fukuda H, Hirono I, Aoki T, Davison AJ, Hedrick RP: Koi herpesvirus represents a third cyprinid herpesvirus (CyHV3 ) in the family Herpesviridae. J Gen Virol 2005;86:1659-1667.

30 Goodwin AE; Khoo L; LaPatra SE; Bonar A; Key DW; Garner M; Lee MV; Hanson L: Goldfish hematopoietic necrosis herpesvirus (cyprinid herpesvirus 2) in the USA: molecular confirmation of isolates from diseased fish. J Aquat Anim Health 2006;18: 11-18.

31 Goodwin AE, Merry GE, Sadler J: Detection of the herpesviral hematopoietic necrosis disease agent (Cyprinid herpesvirus 2) in moribund and healthy goldfish: validation of a quantitative PCR diagnostic method. Dis Aquat Organ 2006;69:137-143.

- 32 Rijsewijk F, Pritz-Verschuren S, Kerkhoff S, Botter A, Willemsen M, van Nieuwstadt T, Haenen O: Development of a polymerase chain reaction for the detection of Anguillid herpesvirus DNA in eels based on the herpesvirus DNA polymerase gene. J Virol Methods 2005;124:87-94.

- 33 Kovács ER, Jánoska M, Dán Á, Harrach B, Benkö M: Recognition and partial genome characterization by non-specific DNA amplification and PCR of a new siadenovirus species in a sample originating from Parus major, a great tit. J Virol Methods 2010;163: 262-268.

-34 Luthra R, Medeiros LF: Isothermal multiple displacement amplification: a highly reliable approach for generating unlimited high molecular weight genomic DNA from clinical specimens. J Mol Diagn 2004;6:236-242.

35 Hellberg H, Koppang EO, Tørud B, Bjerkås I: Subclinical herpesvirus infection in farmed turbot Scophthalmus maximus. Dis Aquat Organ 2002;49:27-31.

36 Graham DA, Curran WL, Geoghegan F, McKiernan F, Foyle KL: First observation of herpes-like virus particles in northern pike, Esox lucius L., associated with bluespot-like disease in Ireland. J Fish Dis 2004;27:543549

37 Iida Y, Nagai T: Detection of flounder herpesvirus (FHV) by polymerase chain reaction. Fish Pathol 2004;39:209-212.

38 Miyazaki T: Ultrastructural features of herpesvirus-infected cells in epidermal lesions in larvae of the Japanese flounder Paralichthys olivaceus. Dis Aquat Organ 2005;66: 159-162. 